\title{
A Study on Expansion Possibilities of Irrigated Areas in Uluırmak Irrigation Basin and Production Planning According to Water
}

\author{
Metin TÜRKER* \\ Ministry of Agriculture and Forest, General Directorate of Agricultural Reform
}

\author{
*Corresponding author e-mail : metin.turker@gmail.com \\ Received : 06.07.2021 \\ Accepted : 27.07.2021 \\ DOI: $10.21657 /$ topraksu. 963463
}

\begin{abstract}
In this study, it is aimed to determine the current irrigation management and performance data in Uluırmak irrigation, to investigate the possibilities of expanding the irrigated areas in the network, and to calculate the optimum production patterns of agricultural enterprises. This study was carried out in 1995 and the results of this study were comparatively reviewed between 1995 and 2020 years. The data used in the study consists of primary data obtained from the surveys conducted with face-to-face interviews with a total of 72 enterprises in the region, determined by stratified sampling method. Linear programming method was used to determine the optimum production patterns according to the current situation in the irrigation basin and the expansion of irrigated areas. The average width of the farmland in the region is 74.42 decares (da), 47.75 da of which is irrigated agricultural land. After the planning made in accordance with the current conditions in the enterprises examined, wheat came to the plan with a maximum of 20.92 da, respectively, sugar beet (9.87 da), sunflower (5.89 da), beans (4.78 da), alfalfa (2.78 da), vegetables (2.89 da), and barley (1.12 da). In addition, the total gross profit of the enterprise reaches $445.4 \mathrm{TL}$, with 2.29 dairy cows (cultural hybrid) and 18.95 sheep coming to the plan in planned production. In case of the completion of the missing investments in the irrigation network and the expansion of the irrigated lands, the irrigated lands will increase by $33.33 \%$ and the gross profit will increase by $60.48 \%$ compared to the current situation and reach $472.4 \mathrm{TL}$. One of the important results of the study is that the average irrigated field land, which is $47.75 \mathrm{da}$, has increased to 64.20 da (34.45\%) with the expansion of irrigated lands and planned water use.
\end{abstract}

Keywords: Production planning, optimization, irrigation management

\section{UluırmakSulamaHavzasındaSulananAlanların Genișletilmesi İmkanları ve Suya Göre Üretim Planlaması Üzerine Bir Çalıșma}

Öz

Bu çalıșmada, Uluırmak sulamasında mevcut durumdaki sulama yönetimi ve performans değerlerinin tespiti ile șebeke içinde fiilen sulanan alanların genișletilme imkanlarının araștırıması ve tarım ișletmelerinin optimum üretim desenlerinin hesaplanması amaçlanmıștır. Çalıșma 1995 yılında yapıımıș olup, o dönemde yapılan çalıșmanın sonuçları ile günümüz (2020) gerçekleșme verileri karșılaștırmalı olarak da incelenmiștir. Araștırmada kullanılan veriler bölgede yer alan, tabakalı örnekleme yöntemiyle belirlenen, toplam 72 adet ișletme ile yüz yüze görüșme yöntemiyle uygulanan anketlerden elde edilen birincil verilerden olușmuștur. Sulama havzasında mevcut durum ve sulanan alanların genișletilmesi durumlarına göre optimum üretim desenlerinin belirlenmesinde ise doğrusal programlama yöntemi kullanılmıștır. Bölgede ortalama ișletme arazisi genișliği 74.42 da olup, bunun 47.75 da sulu tarım 
alanından olușmaktadır. İncelenen ișletmelerde mevcut șartlara göre yapılan planlama sonrasında suluda en fazla 20.92 dekar ile buğday plana gelirken bunu sırasıyla șekerpancarı (9.87 da), ayçiçeği (5.89 da), fasulye (4.78 da ), yonca (2.78 da), sebze (2.89 da) ve arpa (1.12 da) izlemektedir. Ayrica, planlı üretimde ișletme bașına 2.29 süt ineği (kültür melezi) ve 18.95 koyun plana gelmesi ile ișletmenin toplam brüt karı \% 51.33 artarak 445,4 TL'ye ulașmaktadır. Sulama șebekesi içinde eksik yatırımların tamamlanarak fiilen sulanan arazilerin genișlemesi durumunda yapılan planlama ile sulanan araziler, \%33.33 oranında artabilecek ve brüt kar mevcut duruma göre \% 60.48 oranında artarak 472,4 TL'ye yükselecektir. Yapılan araștırmanın önemli sonuçlarından birisi de 47.75 da olan ortalama sulu tarla arazisi sulanan arazilerin genișlemesi ve planlı su kullanımı ile 64.20 da (\% 34.45) yükselmiștir.

Anahtar Kelimeler: Üretim Planlaması, optimizasyon, sulama İ̦letmeciliği

\section{INTRODUCTION}

Improving and using efficiently soil and water resources have become more of an issue in order to meet the basic needs of the population that increase rapidly in the World and also Turkey and to increase the contribution of the agricultural sector to the national economy. While drought and water scarcity-related pressure overproduction has been increasing in recent years, 2050 and 2100 projections have shown that negative effects of water scarcity and drought on production will increase dramatically. Therefore, it is very important to plan production by water asset, to use water as credit, and to produce products consuming less water and having high earning value. To this end it is necessary to review immediately the political, administrative and technical structure about irrigation management and to take essential precautions.

An increase in water demand due to increase in population while water resources are stable causes a raise in the need for water day by day. The useable water amount has been decreasing due to climate change in the World caused by the rapid increase in population and industrialization (Selek and Arslan, 2019). As one examines the studies realized about water and water management, it is seen that most of the studies are about increasing water, which is a scarce resource, with the help of effective and productive use of water and by measuring irrigation performances. In the study realized by Cin and C.akmak (2017), the irrigation performance of Irrigation Cooperative in Ankara Beypazarı Bașören , where irrigation is realized by groundwater, has been assessed. For this purpose, performance indicators for determining water usage effectiveness, agricultural effectiveness and social, and economic effectiveness in the research area have been stated. However, there is a study realized by Uçar and Kara (2016) aiming to determine the effects of land consolidation on water transmission and distribution at the secondary canal level within Isparta-Atabey irrigation network. In addition, there is another study done by Demir (2010) which aims firstly to examine the existing situation of irrigation management, and secondly to detect the main problems of irrigation facilities in Daphan Lowland.

On the other hand, another issue examined by the studies about improving soil and water resources is increasing irrigated areas with irrigation investment constructions. Approximately 6.7 million hectares of total 8.5 million hectares irrigable areas having an economic value have been opened for irrigation in our country. Also, another issue that should be taken into consideration on development of soil and water resources is to ensure effective and productive management of existing irrigation facilities as well as to enlarge irrigated agricultural areas. Regardless of how perfectly an irrigation facility has been built if it is not managed properly and maintenance and repair are not done timely and completely, it is not possible to realize the expected utility from such a facility. Today in our country irrigation facilities are either run by the public institutions or transferred to Irrigation Association, Irrigation Cooperative, Municipality, or Local Authority of Village.

Irrigation plays an important role in the diversification of production patterns and increases in production and income by the transition from dry farming to irrigated farming. Especially in areas such as Central Anatolia where there is arid/semiarid climate, it becomes very important to manage irrigation facilities effectively, increase irrigation 
effectiveness and produce products that can be cultivated on irrigated areas and that provide high economic income to producers. Areas, that are not irrigated while there is an opportunity to get irrigated, should be considered as loss of national wealth. In this context, although there has been an irrigation facility opened in 1965 in Aksaray Uluırmak Basin with the capacity to irrigate 204.400 da it has been detected that there was an irrigation demand for approximately 150.000 da and there was no irrigation demand for 50.000-60.000 da according to data of General Directorate of State Hydraulic Works; therefore the need has emerged to make a research on performance assessment, determination of reasons behind areas that cannot be irrigated and development of solution offers to these reasons. With this study, it is targeted to determine existing irrigation management and performance values of Uluırmak irrigation, search for opportunities to enlarge actually irrigated areas, and calculate optimum production patterns of agricultural enterprises in other words determine optimum production pattern according to water and reveal effects of enlarging irrigated areas of agricultural enterprises on optimum production patterns. However, it is also targeted to review comparatively production planning results in 1995 and today's data.

\section{MATERIAL AND METHOD}

The main material of research has been primary data obtained by questionnaires realized in 1995 with agricultural enterprises existing in Uluırmak irrigation basin. Besides, results of the study carried out in 1995 have been examined comparatively with data in 2020 (comparison of different periods). While realizing economic analysis of agricultural enterprises, coefficients stated in related literature (Açוl and Demirci, 1984; Erkuș et.al., 1995) have been used in specifying workforce potential and stating it as Male Labor Unit. While calculation gross production value of enterprises, sale prices of main and by-product of farmers have been taken into consideration; while calculating gross production value, brut profit and gross revenue that are used to evaluate success levels of enterprises following ways have been used: Gross production value (GPV) has been calculated by multiplying the amount of plant and animal products obtained as the result of agricultural activity with prices obtained by producer and adding the productive increase in plant and animal capital to this amount. Brut profit (BP) has been calculated by deducting changing expenditures from gross production value and Gross Revenue (GR) has been calculated by deducting enterprise expenditures from gross product (Açוl and Demirci, 1984). Also, data of investing institutions such as Irrigation Associations, State Hydraulic Works, and abolished General Directorate of Village Services (GDVS) that are responsible for water management and water distribution services have been utilized.

The main mass in the study has composed of 586 agricultural enterprises selected from the city center of Aksaray Province (8 neighborhoods), 5 towns, and 15 residential areas with village status that were within the right-coast and leftcoast irrigation network of Uluırmak irrigation basin in the year when this study was conducted (1995). Stratified sampling has been applied, questionnaires with 72 enterprises selected as samples have been realized, data has been collected and analyzed.

Unirrigated areas in the network and reasons behind it have been detected together with SHW technical experts by fieldwork; solutions have been offered after detecting planning, project, construction, and managing problems about canal, valve, outlet, field gates, culvert, etc. that block water transfer and also farmer related failing and insufficiencies.

Linear Programming Method has been used to determine optimum management organizations in the current situation and after enlarging actually irrigated areas by completing missing irrigation investments. Linear programming basically ensures to allocate scarce sources between competing activities in the most appropriate way in line with a determined aim. A linear programming model is composed of three main elements: 1. An aim function to be maximized or minimized 2 . Restrictor cluster 3. Condition of decision variables not less than zero (Uzunkaya and Gül, 2017)

\section{RESULTS AND DISCUSSION}

Mamasın Dam which locates at the north east of Aksaray Province $(20 \mathrm{~km})$ is the source of Uluırmak irrigation. Water taken from this dam is brought to a regulator built right outside Aksaray Province $(3 \mathrm{~km})$. Water brought to this regulator is divided into right and left coast main canals. The right-coast main canal is 38,255 meters 
Table 1. Information on Uluırmak Irrigation

Çizelge 1. Uluırmak Sulamasına Ait Bilgiler

\begin{tabular}{|c|c|c|}
\hline Characteristics & 1995 & 2020 \\
\hline \multirow[t]{2}{*}{ Managing Organization } & 1. Right Coast Irrigation Assoc. & \multirow[t]{2}{*}{$\begin{array}{l}\text { Uluırmak Irrigation Assoc. } \\
\text { (Left coast+ right coast) }\end{array}$} \\
\hline & 2.Left Coast Irrigation Assoc. & \\
\hline Irrigation Area (da) & 204.220 & 200.000 \\
\hline Actually Irrigated Area (da) & 133.691 & 142.245 \\
\hline Service Areas & $\begin{array}{l}\text { Total } 25 \text { Settlements (village, neighborhood), } \\
5 \text { of which are municipalities }\end{array}$ & $\begin{array}{l}1 \text { Municipality, } 4 \text { Town, } 14 \text { Villages, } \\
6 \text { Neighborhoods }\end{array}$ \\
\hline \multirow{3}{*}{$\begin{array}{l}\text { Network Feature } \\
\text {-Right Coast Main canal }\end{array}$} & - 38255 m main canal, & \multirow{6}{*}{$\begin{array}{l}\text { Water users from whom declaration } \\
\text { - were collected } 1702 \\
\text { Number of water users } 2607 \\
\text { Rate of declaration collection } 83 \%\end{array}$} \\
\hline & - 12 m3sec ${ }^{-1}$ capacity & \\
\hline & - 12 spare canal & \\
\hline \multirow{3}{*}{-Left Coast Main Canal } & - 14.255 m main canal & \\
\hline & 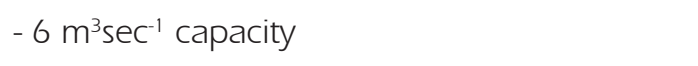 & \\
\hline & - 5 spare canal & \\
\hline
\end{tabular}

and has $12 \mathrm{~m}^{3} \mathrm{sn}^{-1}$ capacity; the left-coast main canal is 14,255 meters and has $6 \mathrm{~m}^{3} \mathrm{sn}^{-1}$ capacity (Anonymous, 1984). Mamasın dam is an irrigation dam and it is projected to provide 138.56*106 $\mathrm{m}^{3}$ irrigation water annually (Anonymous, 1984). Irrigation on the field is realized mostly through auxiliary canals and outlets built on tertiary. Aksaray is a province letting in immigrants and growing rapidly since it is at the intersection of East, South, and Central Anatolia. Due to irregular migration and growing, misuse of productive soils within the network has been increasing day by day; therefore, it is necessary to take irrigation project areas under protection and prevent misuse of areas. Data on irrigation network is stated in Table 1 .

\section{Current Structural Features of Enterprises}

Most of the agricultural enterprises dealing with irrigated farming on Uluırmak irrigation basin are enterprises that realize farming on their private property. Also, type and distribution of lands belonging to examined enterprises are stated in Table 2. The average land size of enterprises is 74.42 da and $95.36 \%$ (70.97) of these lands are field land (irrigated + dry). Furthermore, even if a little, there are vegetable gardens, vineyards, and orchards.

Lands are scattered and fragmented. The numbers of fragments change between 2 and 11 and the average number is 6.53. Although
Table 2. Land Distribution on Farms (1995)

Çizelge 2. Incelenen Iș̦letmelerde Arazi Dağı̆ımı (1995)

Type of Lands of Enterprises Da $\quad$ Da

$\begin{array}{lll}\text { Field Land } & 70.97 \quad 95.36\end{array}$

Irrigated $\quad 47.15$

Dry 23.82

$\begin{array}{lll}\text { Vegetable } & 0.60 & 0.81\end{array}$

$\begin{array}{lll}\text { Fruit } & 0.13 & 0.17\end{array}$

$\begin{array}{lll}\text { Vineyard } & 0.51 & 0.69\end{array}$

$\begin{array}{lll}\text { Woodland } & 0.49 & 0.66\end{array}$

Other $\left({ }^{*}\right) \quad 1.72 \quad 2.3$

\begin{tabular}{lll}
\hline Average of Enterprises & 74.42 & 100.00
\end{tabular}

${ }^{*}$ ) Lands with problems such as high groundwater and salinity

land consolidation has been realized in some parts of the network, fragmentation has been continuing because of the Law of Inheritance. The average population in the examined enterprises is 6.36 persons and the main labor force is the population between ages 15 and 49. The labor force of an enterprise has been calculated as Male Labor Unit (MLU) by age and gender and it is $4.28 \mathrm{MLU}$. Also, the literacy rate in the area is $87.90 \%$ and the rate of people who cannot read and write is $11.60 \%$.

Examined enterprises have been classified according to capital functions. Accordingly, active capital in enterprises is $2293.5 \mathrm{TL}$, and farm capital has constituted the most active capital. Furthermore, in consideration of all enterprises, 
64.79\% of active capital is farm capital and 35.21\% of it is working capital.

\section{Economic Analysis of Enterprises}

In the research area, results of activities such as gross production value, production value, brut profit, gross revenue, and agricultural income of enterprises have been analyzed. The rate of plant production value in total gross production value is calculated as 69.49\%, and ; rate of animal production value is calculated as $30.52 \%$.

Industrial plants have taken the first rank in plant production value with the rate of $60.13 \%$. Cereals have followed industrial plants with the rate of 28.14\% in plant production value and legumes have taken the third place with the rate of $4.89 \%$.

Sugar beet (53.97\%) and sunflower (45.76\%) are industrial plants in plant production value. Mostly wheat (68.10\%) and barley (30.63\%) have been planted as cereals. Dairy farming has taken first place in animal production value with the rate of $11.42 \%$ and inventory value increase has followed this with $10.20 \%$ and sheep breeding has come behind with $8.44 \%$.

Gross revenue of examined enterprises that indicates the success of enterprises has been calculated as 173.7 TL and agricultural income, another success indicator, has been detected as $211.4 \mathrm{TL}$.

\section{Irrigation Results and Performance Evaluation of Uluırmak Irrigation}

The distribution of plants irrigated in the irrigation area in some selected years has been indicated in Table 3. While in the period of research the most important plants cultivated with irrigation were cereals, sunflower, and sugar beet, in the following years' cereals have protected their importance in the area and also in times of drought cultivation rate of cereals had increased, but then it has seen that important changes in production pattern had emerged later. With the increase in income obtained from sunflower, its production area has increased dramatically and the production area of sugar beet has decreased due to the quota applied by the government. Change in production pattern has led to change in water consumption and irrigation water demand.
Table 3. Distribution of Plants Irrigated by Uluırmak Irrigation Çizelge 3. Uluırmak Sulaması Sulanan Bitkilerin Dağıımı (\%)

\begin{tabular}{lcccccc}
\hline Irrigated Plants & 19952000 & 2005 & 2010 & 2015 & 2020 \\
Cereals & 45 & 48 & 64 & 47 & 40 & 50 \\
Sugar beet & 17 & 17 & 9 & 6 & 4 & 2 \\
Sunflower & 24 & 27 & 17 & 35 & 40 & 31 \\
Legumes & 3 & 0 & 0 & 0 & 0 & 0 \\
Maize & 0 & 0 & 4 & 3 & 5 & 6 \\
Fodder Crop & 5 & 2 & 4 & 6 & 7 & 8 \\
Water-melon & 2 & 0 & 0 & 1 & 0 & 0 \\
Fruit & 2 & 1 & 1 & 1 & 1 & 1 \\
Vegetable & 2 & 0 & 1 & 1 & 1 & 1 \\
Other (onion, garlic) & 0 & 5 & 0 & 0 & 2 & 1 \\
\hline Total & 100 & 100 & 100 & 100 & 100 & 100
\end{tabular}

On the other hand, Uluirmak irrigation network is open canal irrigation and most of the farmers realize surface irrigation, they pay the cost of irrigation according to plant variety and land size irrigated, so the cost of irrigation changes with the size of enterprises. Rate of cost of irrigation under total enterprise costs changes between 2.61\% and $3.27 \%$.

The productivity of irrigation networks has been measured by performance evaluation. To this end, criteria such as irrigation rate, irrigation efficiency, plant pattern, irrigation price, realization and collection rates are utilized. Irrigation results and performance indicators in Uluırmak irrigation area (left-coast and rightcoast) in 1995 and 2000 have been indicated in Table 4.

As indicated in Table 4 although the amount of water per hectare has decreased irrigation rate has been 63\% and the irrigation efficiency rate has been 65\% in 2000 while the irrigation rate was $65 \%$ and the irrigation efficiency rate was 45\% in 1995. One of the most important factors behind this increase in rates has been the use of sprinkler and drip irrigation systems which are types of pressurized irrigation systems by the farmers in recent years. Reasons for not irrigating have been stated in Table 5.

Management and maintenance and repair services of Uluırmak irrigation have been transferred to Right Coast Irrigation Association and Left Coast Irrigation Association in 
Table 4. Uluırmak Irrigation Performance Indicators for 1995 and 2020 Period

Çizelge 4. Uluırmak Sulaması 1995 ve 2020 Dönemi Performans Göstergeleri

\begin{tabular}{lcc}
\hline Indicators & 1995 & 2020 \\
\hline Irrigation Project Area (da) & 204.220 & 200.000 \\
Area for which irrigation demanded (da) & 150.191 & 150.000 \\
Actually Irrigated Area (da) (\% 89.5) & 133.691 & 126.220 \\
Irrigation Rate (\%) & 65 & 63 \\
Water Amount within the Network $\left(\mathrm{hm}^{3}\right.$ year $\left.^{-1}\right)$ & 105.581 & 63.460 \\
Amount of Water per Hectare $\left(\mathrm{hm}^{3} \mathrm{year}^{-1}\right)$ & 7.897 & 4.922 \\
Need for Irrigation Water $\left(\mathrm{hm}^{3} \mathrm{year}^{-1}\right)$ & 3.529 & 3.198 \\
Irrigation Efficiency (\%) & 45 & 65 \\
Efficiency to-be (\%) & 54 & 54 \\
Realization/Collection Rate (\%) & 61 & 62 \\
\hline
\end{tabular}

Table 5. Reasons for Not Irrigating Fields in Uluırmak Irrigation

Çizelge 5. Uluırmak Sulamasında Alanların Sulanamama Nedenleri

\begin{tabular}{lccc}
\hline \multirow{2}{*}{ Reasons } & \multicolumn{2}{c}{ 1995 } & 2020 \\
\cline { 2 - 4 } & Right Coast IA & Left Coast IA & Uluırmak IA \\
\hline Sufficient Rain & 12.540 & 1.291 & 0 \\
Insufficient Canal & 44.000 & 6.000 & 50.000 \\
Insufficiency in Outlets, Settings & 500 & 0 & 0 \\
Neighbor Conflicts & 500 & 100 & 200 \\
Irrigation with Private Opportunities & 2500 & 300 & 10.260 \\
Total & 60.040 & 7.691 & 60.460 \\
\hline
\end{tabular}

1994. However, network insufficiencies and deficiencies in maintenance and repair services have decreased irrigation performance. Irrigated area has decreased due to the inability to serve to the total area planned to be irrigated by the network because of lack of investments. Thus, according to data of irrigation associations (according to water demand receipts) in 1995 , irrigation demand for 150.191 da of total 204.420 da network area and 133.691 da (65.45\%) of irrigation area could be irrigated. In 2020126.220 da of 150.000 da for which irrigation demand has been realized have been irrigated. Although 25 years have passed, 82.3\% of unirrigated areas cannot be irrigated because of insufficient canals.

On the other hand, considering the cost of water and irrigation, there are no water measurement facilities in Uluırmak irrigation area and charging of irrigation water has still be realized according to product and decare. Irrigation charges have been taken according to the area (TLda ${ }^{-1}$ ) taking the water budget and expenditures of the Association into consideration. Water demand bills have been collected before irrigation season and water distribution plans have been prepared and applied according to water reserve. Also, some sanctions have been imposed on persons damaging the facility and realizing transactions inconsistent with irrigation orders. Actions such as causing material damage to the irrigation system, not using irrigation system appropriately, causing pollution, preventing the flow of water, not obeying water limitations determined by Association officers, not obeying restricted product, restricted area, restricted day and hour implementations, not signing Irrigation Contract (declaration form) until 15th of March in every year are subject to sanctions. Also, it has been accepted and put into force to impose penalty to persons who don't pay debts to Irrigation Association on time according to the Law of Obligations. 


\section{Expansion Possibilities of Irrigated Areas and Developments Obtained}

In this part, it has been aimed to compare developments in 2020 with activities that need to be done in order to ensure irrigation of unirrigated areas in irrigation area determined in research date. Developments in both periods and the comparison of these developments have been indicated in Table 6.

As indicated in Table 6 investments necessary to expand irrigated areas have not been realized yet. In addition to this, it has been decided and included in the program to transform some part of the irrigation network to a closed system, but could not be initialized due to insufficient allocation. In this context, it is very important to transform the system to closed irrigation system, to train and raise awareness of farmers about irrigation, to ensure maintenance and repair, not to cultivate plants consuming too much water, and to use water in a controlled way.

\section{Results of Planning}

In this part results of comparison between existing production pattern of enterprises dealing with irrigated farming in Uluırmak irrigation basin and optimum enterprise organization determined through linear programming method in case of continuation of the current situation and in case of expanding irrigated areas by completing investments have been stated.

The most cultivated product in the research area has been wheat with 16.26 da cultivation area on irrigated areas; sunflower has taken the second place with 14.71 da cultivation area and then sugar beet with 7.91 da and barley 7.36 da have followed them. Total brut profit of enterprises has been determined as 294.342.502 TL. According to planning realized under current conditions for examined enterprises on irrigated land, wheat has taken the first rank with 20,92 da; sugar beet with $9.87 \mathrm{da}$, sunflower with 5.89 da, bean with 4.78 da, alfalfa with 2.78 da, vegetable with 2.89 da, and barley with 1.12 da have followed wheat. Also, after planning each enterprise has had 2.29 dairy cattle (cultured crossbreed) and 18.95 sheep and the total brut profit of an enterprise have increased to 445.4 TL with an increase of $51.33 \%$.

After planning in case of expanding irrigated areas by completing investments within the irrigation network, irrigated areas would increase at the rate of $33.33 \%$ and brut profit would increase to $472.4 \mathrm{TL}$ with an increase of $60.48 \%$.

Another important result of this research is that 16.49 da $(90.43 \%)$ of the average 18.59 da dry farming area within the network can be irrigated economically after investment. Thus, 47.75 da

Table 6. Identified Deficiencies in Uluırmak Irrigation and Current Situation

Çizelge 6. Uluırmak Sulamasında Belirlenen Eksiklikler ve Mevcut Durum

\begin{tabular}{|c|c|}
\hline \multicolumn{2}{|l|}{ Years } \\
\hline 1995 & 2020 \\
\hline $\begin{array}{l}\text { Increasing capacity of right coast main canal (increase from } 12 \mathrm{~m}^{3} \mathrm{sec}^{-1} \text { to } 16 \mathrm{~m}^{3} \mathrm{sec}^{-1} \\
18 \mathrm{~km} \text { ) }\end{array}$ & $\begin{array}{l}\text { Cannot } \\
\text { be realized }\end{array}$ \\
\hline $\begin{array}{l}\text { Constructing soil tertiary canal (Tavșancıl canal /1.150 m) on Spare-1 as concrete canal } \\
\text { (3500 da) }\end{array}$ & $\begin{array}{l}\text { Cannot } \\
\text { be realized }\end{array}$ \\
\hline Constructing 1 km soil canal following Spare-1 canal as concrete canal (1000 m) & $\begin{array}{l}\text { Cannot } \\
\text { be realized }\end{array}$ \\
\hline Increasing Spare-2A canal capacity (2200 m) & $\begin{array}{l}\text { Cannot } \\
\text { be realized }\end{array}$ \\
\hline Opening a new spare canal between Spare-7 and Spare-8 (3500 da) & $\begin{array}{l}\text { Cannot } \\
\text { be realized }\end{array}$ \\
\hline Opening a spare canal between Spre-4 and Spare-5 & $\begin{array}{l}\text { Cannot } \\
\text { be realized }\end{array}$ \\
\hline Repair and restoration of outlets and settings & $\begin{array}{l}\text { Outlets and settings are } \\
\text { repaired every year. }\end{array}$ \\
\hline Updating enterprise map & $\begin{array}{l}\text { No updated } \\
\text { map }\end{array}$ \\
\hline
\end{tabular}


which is the average irrigated agricultural land within network would increase to 64.20 da (34.45\%).

The size of the area where cereals are cultivated and which is 22.04 da of the irrigated area under planning in the current situation will increase to 30.61 da of the irrigated area with an increase of 8.57 da in planning in case of expanding irrigated area. The size of the area where industrial plants are cultivated and which is 15.76 da in the current situation will increase to 21.18 da under planning in case of expanding irrigated area. Furthermore, size of the area where the vegetable is cultivated will increase from 2.39 to 3.21 da with increase in irrigated area.

Considering the animal production, dairy cattle breeding (2.29 Production Unit) and sheep breeding (18.95) have been planned in accordance with barn and fold capacity. Since barn and fold capacity have been used fully under the current situation, there has been no change in terms of animal assets under planning after investment.

Consequently, $52.10 \%$ of the irrigated area after expanding is utilized for cultivating cereals, 32.94\% for industrial plants, 9.97\% for legumes, and $4.98 \%$ for vegetable growing.

\section{CONCLUSIONS}

It is seen that most of the deficiencies in relation to the subject of this research have not been completed when the period of research (1995) is compared to the recent situation. However, measures taken against structural problems of enterprises (heritage, fragmentation, etc) have partial positive effects. In this context, in order to utilize soil and water resources in the research area more effectively and productively, it becomes necessary in the service area of irrigation network to solve structural problems about irrigation network like increasing canal capacity when needed, to transform soil canals to concrete covered or piped canals, build new spare canals when needed, meet deficiencies in water receiving structures such as settings and outlets and drainage deficiencies.

At the same time, it would be beneficial for the region to make some arrangements about cooperation between the public, irrigation associations and farmers, and especially to ensure participation of farmers more actively in management and maintenance and repair services. Also, training of staff of irrigation association and farmers for efficiency of irrigation and agricultural activity and completing in-field development services such as drainage, levelling and land improvement needed within irrigation network become more of an issue.

Water loss is high in the region because of open and old canals of irrigation network. Systematically extending the use of modern irrigation systems ensuring water savings, extreme increase in input prices, difficulty in accessing credit, and an increase in expenditures cause increase in irrigation costs.

Fodder crop growing level is below where it needs to be even on irrigated areas. It would be beneficial to encourage fodder crop growing in the region especially for improving animal breeding.

\section{REFERENCES}

Açıl AF, Demirci R (1984). Tarım ekonomisi dersleri, A.Ü.Ziraat Fakültesi Yayınıarı: 880, Ankara.

Açıl AF (1976). Tarımsal ürün maliyetlerinin hesaplanması ve memleketimizde tarımsal ürün maliyetlerindeki gelișmeler, A.Ü.Ziraat Fakültesi Yayınları: 665, II. Baskı. Ankara.

Anonim (1976). DSi sulama tesisleri ișletme talimatı, DSi Yayınları, Yayın No: 20, Ankara.

Anonim (1992). DSi ișletme bakım mühendisleri semineri, DSi Yayınları, Yayın No: 110 Ankara.

Anonim (1992b), Turkey irrigation management and investment review, world bank discussion draft. Number: 1

Anonim (1993). Sulu tarımda etkin çiftci katııımı, KHGM Sulama Dairesi Bșk. Yayınları, Ankara.

Anonim (1993b) Türkiyede sulu tarım yatırımlarına ișletme ve bakım faaliyetlerine çiftci katıııı inceleme raporu, KHGM yayınları, Ankara.

Anonim (1993c) Türkiyede sulu tarım yatırımlarına ve ișletme, bakım faaliyetlerine çiftci katılımı, Ulusal Çalıșma Grubu Dökümanları.

Anonim (1993d). GAP sulama alanlarında çiftci örgütlenmesi ve sulama sistemi yönetimi F. Ebert Vakfı Yay. Ankara.

Anonim (1994). GAP MOM study management, operation and maintanance of GAP irrigation systems, identification report, Volum I Maintaks, Dolsar+Halcrow+ RWC Joint Venture Companies, Ankara.

Anonim (1994a). DSi ișletme bakım dairesi, 1993 yılı Üretim Sonuçları, Ankara.

Anonim (1994b). 1994 yllı sulama ve kurutma tesisleri, ișletme, bakım ve yıllık yatırım ücret tarifeleri, DSi Basımevi, Ankara. 
Anonim (1994c). Toprak ve su kaynaklarının geliștirilmesi bildirileri DSi 40. yıl kutlamaları, DSi yayınları, Ankara.

Anonim (2021). Uluırmak Sulama Birliği Dokümanları

Cin S, Çakmak B (2017), Ankara Beypazarı Bașören Sulama Kooperatifi'nde sulama performansının değerlendirilmesi, Gaziosmanpașa Üniversitesi Ziraat Fakültesi Dergisi, 34 (2): 10-19. doi:10.13002/jafag4221

Demir O (2010). Daphan ovası sulama tesislerinden yararlanan tarım ișletmelerinin fiziki ve sosyo ekonomik kaynaklı ișletme sorunları ve çözüm olanaklarının belirlenmesi, Atatürk Üniversitesi Ziraat Fakültesi Dergisi, 41 (1): 19-27.

Erkuș A, Bülbül M, Kıral T, Açıl AF, Demirci R (1995). Tarım Ekonomisi, A.Ü.Ziraat Fakültesi Eğitim, Araștırma ve Geliștirme Vakfı Yayınları No: 5, Ankara.
Erkus A, Türker M (1994). Türkiye'de sulama ișletmecilik șekilleri, çiftci ve köy dünyası, TZOB, S. 117-118, Ankara.

Selek Z, Arslan C (2019). Entegre Su Kaynakları Yönetiminde WEAP Modelinin Kullanılması: Burdur Gölü Havzası Örneği, Gazi Mühendislik Bilimleri Dergisi, 5 (1): 54-64

Uçar Y, Kara M (2016). Arazi toplulaștırmasının su iletim ve dağıtım performansına etkisi, KSÜ. Fen ve Mühendislik Dergisi, 9 (1): 2006.

Uzunkaya K, Gül M (2017). Dinar Karakuyu sulaması sahası tarımsal ișletmelerinin doğrusal programlama yöntemi kullanılarak ürün desenlerinin planlanması, Süleyman Demirel Üniversitesi Fen Bilimleri Enstitüsü Dergisi 21 (2): 388-396. doi: 10.19113/sdufbed. 96241 